\title{
UJI EFEK HIPOGLIKEMIK EKSTRAK ETANOL BUAH SAWO MANILA (Manilkara zapota) PADA MENCIT JANTAN YANG DIINDUKSI ALOKSAN
}

\author{
Safriani Rahman, Aulia Wati \\ Fakultas Farmasi Universitas Muslim Indonesia, Makassar \\ Email : safriani_rahman@yahoo.com.
}

\begin{abstract}
Diabetes mellitus is a metabolic disorder of carbohydrate, fat and protein that is characterized of hyperglycemia. Manila sapodilla (Manilkara zapota) empirically has been used by people as a traditional medicine. This study aims to determine the hypoglycemic effects and an effective concentration of ethanol extract manila sapodilla fruit as hypoglycemic on male mice induced by alloxan. The group of test animals consisted of 25 mice balb / c males were divided into 5 groups. Negative control group Na.CMC suspension $1 \% \mathrm{w} / \mathrm{v}$, the comparison group glibenclamide $0.65 \mathrm{mg} / \mathrm{kgbw}$, and group 3, 4, and 5 are a group of ethanol extract manila sapodilla fruit (EBSM) at a doses of $250 \mathrm{mg} / \mathrm{kgbw}, 500 \mathrm{mg} / \mathrm{kgbw}$, and $750 \mathrm{mg} / \mathrm{kgbw}$. Before treatment all test animals alloxan induced a dose of $150 \mathrm{mg} / \mathrm{kgbw}$ intraperitoneally (i.p). Given the test preparation is done orally once daily for 21 days. Blood collection from tail vein of mice on day 1 ( $h$ - 3rd), -3, -7, -11, -14, -17 and days 21 during treatment. Measurement of blood glucose levels is done before induction as early glucose levels, glucose levels after induction as diabetes mellitus, and after the end of therapy as glucose levels. The results were analyzed statistically by t-test and one-way ANOVA. Results showed EBSM a dose of $250 \mathrm{mg} / \mathrm{kgbw}$ showed no significant different compared to glibenclamide suspension. From this study it can be concluded that manila sapodilla fruit extract has hypoglycemic effects with an effective dose of $250 \mathrm{mg} / \mathrm{kgbw}$.
\end{abstract}

Keywords : Hyperglycemia, Manilkara zapota, male mice, alloxan.

\section{PENDAHULUAN}

Diabetes mellitus

(DM)

merupakan penyakit gangguan metabolisme karbohidrat, lemak, dan protein yang ditandai dengan keadaan hiperglikemia akibat kurangnya sekresi insulin atau kerja insulin. Hiperglikemia dapat disebabkan karena pembentukan radikal bebas yang berlebih dan memicu terjadinya stress oksidatif melalui mekanisme glikasi non enzimatik protein, autooksidatif glitation aktivasi protein kinase dan peningkatan jalur poliol. Reaktive oxygen species (ROS) berkontribusi menyebabkan disfungsi dan kerusakan jaringan sel beta pancreas. $^{1-2}$

Penderita diabetes memerlukan asupan antioksidan dalam jumlah yang 
Uji Efek Hipoglikemik Ekstrak Etanol Buah Sawo Manila (Manilkara zapota) Pada Mencit Jantan Yang Diinduksi Aloksan

besar untuk mengurangi terbentuknya radikal bebas baru yang diakibatkan karena keadaan hiperglikemia. Antioksidan dapat diperoleh dari asupan luar. Salah satu tanaman yang diidentifikasi sebagai sumber yang kaya akan antioksidan adalah buah sawo manila (Manilkara zapota). Buah sawo manila memiliki kandungan kimia tanin , karotenioid, saponin dan flavonoid. Selain itu pada daging buah sawo juga mengandung lemak, protein, vitamin $A, B$, dan $C$, mineral, besi, kalsium, fosfor dan asam folat ${ }^{2-3}$ Kandungan kimia flavonoid dan polifenol mempunyai efek sebagai antioksidan yang dapat mengatasi stress oksidatif. Selain itu juga dapat meningkatkan pelepasan insulin dari sel beta pankreas dan pengambilan kalsium serta menghambat penyerapan karbohidrat dalam saluran cerna. ${ }^{4}$ Telah dilakukan penelitian oleh $\mathrm{Ma}$ et al. (2003) pada buah sawo manila dan ditemukan dua senyawa antioksidan baru yang aktivitas antioksidannya sangat tinggi yaitu methyl 4-O-galloylchlorogenate dan 4O-galloylchlorogenic acid dengan nilai $\mathrm{IC}_{50}$ masing-masing sebesar $12.9 \mu \mathrm{M}$ dan $23,5 \mu \mathrm{M}$. $^{5}$

Berdasarkan uraian diatas, ditinjau dari kandungan kimia buah sawo manila dan belum ada data ilmiah pengujian diabetes mellitus maka akan dilakukan penelitian uji efek hipoglikemik ekstrak etanol buah sawo manila pada mencit jantan yang diinduksi aloksan.

\section{METODE PENELITIAN}

\section{Lokasi Penelitian}

Penelitian ini dilakukan di Laboratorium Farmakologi dan Fitokimia Fakultas Farmasi Universitas Muslim Indonesia.

\section{Bahan yang digunakan}

Etanol $70 \%$, buah sawo manila (Manilkara zapota), Natrium CMC, air suling, kertas saring, aluminium foil, pakan hewan, strip glukometer, glibenklamid.

\section{Prosedur Kerja}

Pengambilan dan Pengolahan Sampel

Buah diambil pada waktu pagi hari sekitar jam 10.00. sampel dibersihkan dari kotoran yang melekat dengan menggunakan air yang mengalir lalu dipotong kecil-kecil kemudian dikeringkan dibawah sinar matahari langsung hingga jam 11 pagi dan diangin-anginkan. Setelah kering sampel dihaluskan.

\section{Pembuatan Ekstrak}

Sebanyak 500 gram dimasukkan dalam wadah maserasi, ditambahkan etanol 96\%, dibiarkan selama 1x24 jam dalam bejana 
Uji Efek Hipoglikemik Ekstrak Etanol Buah Sawo Manila (Manilkara zapota) Pada Mencit Jantan Yang Diinduksi Aloksan

tertutup dan terlindung dari cahaya sambil diaduk selama 6 jam dan dibiarkan selama 18 jam. Setelah itu simplisia disaring dan ampasnya direndam lagi dengan cairan yang baru hal ini dilakukan sebanyak 5 kali. Hasil penyarian yang didapat kemudian dikumpulkan dan di uapkan dengan menggunakan rotavapor hingga diperoleh ekstrak etanol yang kental. $^{6}$

\section{Pembuatan Suspensi Glibenklamid} dosis $0,65 \mathrm{mg} / \mathrm{kgbb}$

Serbuk yang telah digerus ditimbang sebanyak 12,3459 mg kemudian disuspensikan dengan Na.CMC sedikit demi sedikit hingga homogen. Masukkan dalam labu ukur dan dicukupkan volumenya hingga 25 $\mathrm{ml}$.

\section{Pembuatan Aloksan $150 \mathrm{mg} / \mathrm{kgbb}$}

Sebanyak 112.5 mg, kemudian dilarutkan dengan $\mathrm{NaCl}$ fisiologi sedikit demi sedikit hingga larut rata, dicukupkan volumenya hingga $25 \mathrm{~mL}$.

\section{Pembuatan Ekstrak Uji}

Ekstrak buah sawo manila (EBSM) yang dibuat adalah dosis 250 $\mathrm{mg} / \mathrm{kgbb}, \quad 500 \mathrm{mg} / \mathrm{kgbb}$ dan 750 $\mathrm{mg} / \mathrm{kgbb}$. Untuk membuat dosis 250 $\mathrm{mg} / \mathrm{kgbb}$ yaitu ditimbang ekstrak sebanyak $75 \mathrm{mg}$ (7,5 mg/30 gr mencit) kemudian di larutkan dalam $10 \mathrm{ml}$
Na.CMC $1 \%$ b/v. Untuk membuat EBSM dosis $500 \mathrm{mg} / \mathrm{kgbb}$ dan 1000 $\mathrm{mg} / \mathrm{kgbb}$ masing-masing ditimbang $150 \mathrm{mg}$ dan $225 \mathrm{mg}$.

\section{Pengambilan darah hewan uji}

Setelah itu ekor mencit diberikan desinfektan dengan etanol $70 \%$ dan ujung ekor (vena ekor) dipotong sedikit dengan mengambil darah pada tetesan yang ke-dua. ${ }^{7}$

\section{Perlakuan Hewan Uji}

Setelah diukur kadar glukosa darah awal, kemudian mencit diinduksi aloksan dengan dosis 150 $\mathrm{mg} / \mathrm{kgbb}$ secara intraperitoneal (i.p) dan diukur kadar glukosa darah setelah induksi selama $3 \times 24$ jam hingga diperoleh kadar glukosa darah mencit $\geq 200 \mathrm{mg} / \mathrm{dL} .{ }^{8}$ Pemberian sediaan uji dilakukan peroral satu kali sehari terhadap semua kelompok perlakuan selama 21 hari berturut-turut kecuali kelompok normal. Pengambilan cuplikan darah dilakukan dari vena ekor mencit pada hari ke-1 (jam ke-3), -3, -7, -11, -14,-17 dan hari ke-21 selama perlakuan.

\section{Analisis Data}

Data penelitian yang diperoleh, dikumpulkan dan dianalisis dengan menggunakan metode statistik uji ttest berpasangan dan Anova satu arah. 
Uji Efek Hipoglikemik Ekstrak Etanol Buah Sawo Manila (Manilkara zapota) Pada Mencit Jantan Yang Diinduksi Aloksan

\section{HASIL PENELITIAN}

Tabel 1.Hasil Pengukuran Rata-Rata Kadar Glukosa Darah Awal, Induksi, Terapi

\begin{tabular}{|c|c|c|c|c|c|}
\hline No & Kelompok & $\begin{array}{c}\text { KGD puasa } \\
\pm \text { SD }\end{array}$ & $\begin{array}{l}\text { KGD Induksi } \\
\pm \text { SD }\end{array}$ & $\begin{array}{c}\text { KGD Terapi }(+21) \\
\pm \text { SD }\end{array}$ & P (95\%) \\
\hline 1 & $\begin{array}{l}\text { Suspensi } \\
\text { Na.CMC } 1 \% \text { b/v }\end{array}$ & $76,3 \pm 10,3$ & $283,0 \pm 39,0$ & $280,0 \pm 23,3$ & \\
\hline 2 & $\begin{array}{l}\text { Glibenklamid } \\
0,65 \mathrm{mg} / \mathrm{kgbb}\end{array}$ & $79,7 \pm 4,7$ & $257,7 \pm 14,6$ & $80,0 \pm 5,3$ & \\
\hline 3 & $\begin{array}{l}\text { EBSM dosis } \\
250 \mathrm{mg} / \mathrm{kgbb}\end{array}$ & $76,7 \pm 12,2$ & $298,7 \pm 21,8$ & $79,7 \pm 19,5$ & 0,000 \\
\hline 4 & $\begin{array}{l}\text { EBSM dosis } \\
500 \mathrm{mg} / \mathrm{kgbb}\end{array}$ & $65,0 \pm 8,7$ & $262,0 \pm 35,8$ & $231,3 \pm 43,3$ & \\
\hline 5 & $\begin{array}{l}\text { EBSM dosis } \\
1000 \mathrm{mg} / \mathrm{kgbb}\end{array}$ & $68,3 \pm 7,6$ & $312,0 \pm 55,5$ & $237,0 \pm 84,5$ & \\
\hline
\end{tabular}

\section{PEMBAHASAN}

Penentuan efek hipoglikemik ekstrak etanol buah sawo manila (Manilkara zapota) pada mencit jantan yang diinduksi aloksan dilakukan dengan mengukur kadar glukosa darah mencit (Mus musculus). Kadar glukosa darah diukur dengan menggunakan pankreas yang prinsip kerjanya secara enzimatik melibatkan reaksi glukosa oksidase, yang menghasilkan intensitas warna yang akan dideteksi oleh alat ini. Metode ini sederhana, spesifik untuk glukosa sehingga tidak terganggu dengan adanya bahan pereduksi lain. Selain itu pada metode ini dapat memberikan hasil yang mendekati kadar glukosa darah sesungguhnya.

Penelitian ini menggunakan mencit jantan, yang memiliki sistem hormonal yang lebih stabil dibandingkan mencit betina yang memiliki kadar glukosa darah lebih tinggi saat hamil sehingga dapat mempengaruhi data hasil penelitian. Walaupun demikian, faktor variasi biologis dari hewan uji tidak dapat dihilangkan sehingga faktor ini relative dapat mempengaruhi hasil. Oleh karena itu terdapat perbedaan konsentrasi kadar glukosa darah awal pada tiap hewan coba.

Pada tabel 1 menunjukkan data hasil pengukuran kadar glukosa darah awal dan setelah induksi untuk tiap kelompok perlakuaan yang selanjutnya dilakukan analisis statistic uji t-test berpasangan. Dari uji statistik menujukkan kadar glukosa darah awal berbeda nyata terhadap kadar glukosa induksi, yang berarti penginduksian aloksan berhasil meningkatkan kadar glukosa awal. Hal ini terlihat bahwa akibat induksi aloksan secara intraperitoneal dosis $4,5 \mathrm{mg} / 30 \mathrm{~g}$ 
Uji Efek Hipoglikemik Ekstrak Etanol Buah Sawo Manila (Manilkara zapota) Pada Mencit Jantan Yang Diinduksi Aloksan

setelah tiga hari induksi terjadi peningkatan kadar glukosa darah $\geq$ $200 \mathrm{mg} / \mathrm{dl}$. Kondisi ini dapat terjadi karena aloksan dapat menghasilkan radikal hidroksil yang sangat reaktif dan dapat menyebabkan diabetes pada hewan percobaan. Mekanisme aksi dapat menimbulkan pengrusakan belum diketahui dengan jelas. Diduga aloksan secara selektif merusak sel $\beta$ pancreas yang mensekresi insulin. Dengan rusaknya sel $\beta$ maka sekresi insulin menjadi berkurang, sementara itu sekresi glucagon oleh sel $\alpha$ tetap berlangsung sehingga mengakibatkan regulasi insulin-glukagon terganggu yang mengakibatkan meningkatnya kadar glukosa darah.

Sampel yang digunakan dalam penelitian ini adalah ekstrak etanol buah sawo manila dosis $250 \mathrm{mg} / \mathrm{kgbb}$, $500 \mathrm{mg} / \mathrm{kgbb}$, dan $1000 \mathrm{mg} / \mathrm{kgbb}$. Ekstrak etanol buah sawo manila mengandung polifenol, dan vitamin yang diduga dapat berkhasiat sebagai antioksidan yang dapat mengatasi radikal bebas. Kandungan kimia flavonoid dan polifenol mempunyai efek sebagai antioksidan yang dapat mengatasi stress oksidatif. Selain itu juga dapat meningkatkan pelepasan insulin dari sel beta pankreas dan pengambilan kalsium serta menghambat penyerapan karbohidrat dalam saluran cerna. ${ }^{2}$

Hasil penelitian menunjukkan secara statistik anova dan uji lanjutan LSD rata-rata kadar glukosa terapi pada hari ke-21. Ekstrak buah sawo manila (EBSM) dosis $250 \mathrm{mg} / \mathrm{kgbb}$ tidak berbeda nyata terhadap kelompok suspensi glibenklamid sebagai pembanding. Hal ini berarti EBSM dosis $250 \mathrm{mg} / \mathrm{kgbb}$ memiliki efek yang sama dengan glibenklamid dalam menurunkan kadar glukosa darah. Hal ini juga ditunjukkan pada gambar 1 dari grafik penurunan ratarata kadar glukosa darah yang memperlihatkan rata-rata penurunan kadar glukosa darah kelompok EBSM dosis $250 \mathrm{mg} / \mathrm{dl}$ hamper sama dengan kelompok suspensi glibenklamid. Kelompok EBSM dosis $500 \mathrm{mg} / \mathrm{kgbb}$ dan $1000 \mathrm{mg} / \mathrm{kgbb}$ menunjukkan berbeda nyata terhadap kelompok EBSM dosis $250 \mathrm{mg} / \mathrm{kgbb}$. Hal ini berarti bahwa kelompok EBSM dosis 500 dan $1000 \mathrm{mg} / \mathrm{kgbb}$ tidak memiliki efek yang sama dengan EBSM dosis $250 \mathrm{mg} / \mathrm{kgbb}$ dalam menurunankan kadar glukosa namun tetap terjadi penurunan meskipun tidak berarti.

\section{KESIMPULAN}

Dari hasil penelitian dapat disimpulkan bahwa ekstrak buah sawo manila (Manilkara zapota) memiliki 
Uji Efek Hipoglikemik Ekstrak Etanol Buah Sawo Manila (Manilkara zapota) Pada Mencit Jantan Yang Diinduksi Aloksan

efek hipoglikemik dan ekstrak dosis $250 \mathrm{mg} / \mathrm{kgbb}$ merupakan dosis efektif sebagai hipoglikemik.

\section{DAFTAR PUSTAKA}

1. Setiawan B, Suhartono E. Stress Oksidatif dan Peran Antioksidan pada Diabetes Melitus. Jakarta, 2005.

2. Gomathy K, Baskar R, Kumaresan, K. Comparison of antioxidant potential in pulp and peel extracts of Manilkara zapota (L.) P Royen African Journal of Biotechnology 2013; 12(31):4936-4943.

3. Hakimah, Ainun I. 81 Macam buah Berkhasiat Istimewa. Jawa Tengah: Syura Media Utama, 2010.

4. Tapas AR, Sakarkar DM, Kakde RB. Flavonoids as nutraceuticals: A Review. Tropical Journal of
Pharmaceutical Research 2008; 7: 1089-1099.

5. Ma, Jun et al. Bioactive Novel Polyphenols from the Fruit of Manilkara zapota (L.) P Royen (Sapodilla) 2003; 66(7):983-986.

6. Depkes RI. Farmakope Herbal Indonesia Edisi I. Jakarta, 2010.

7. Tanquilut NC, Tanquilut MAC, Torres EB, Rosario JC, Reyes BAS. Hypoglycemic effect of Lagerstroemia speciosa (L.) Pers. on alloxan-induced diabetic mice. Journal of Medicinal Plants Research 2009; 3(12):1066-1071.

8. Etuk EU. Animals models for studying diabetes mellitus. Agriculture And Biology Journal Of North America 2010;1(2): 130-134. 